\title{
The Solution to Sociology
}

Paul TE Cusack ${ }^{*}$

Sandy Point Rd, Saint John NB, Canada

*Corresponding Author: Paul TE Cusack, 1641 Sandy Point Rd, Saint John NB E2K 5E8, Canada, Tel: (506) 214-3313; E-mail: St-michael@hotmail.com Rec Date: Mar 29th, 2017; Acc Date: May 11th, 2017; Pub Date: May 20th,2017

Copyright: (C) 2017 Cusack PTE. This is an open-access article distributed under the terms of the Creative Commons Attribution License, which permits unrestricted use, distribution, and reproduction in any medium, provided the original author and source are credited.

\section{Abstract}

Here is a brief paper explain the importance of the ten commandments given to Moses by god which formed the foundation of the greatest civilization in human history.

Keywords: Sociology; Society; Ten commandments; Decalogue

\section{Introduction}

Sociology is the study of Human Society. If we have no society, we have no Sociology to speak about. Society requires cooperation between its members.

Humanities matter because they are an Art. They are what makes us human. They require creativity. God created human beings to live one another. He loved us. "Its nots that we love Him; it's that He loved us first." An Art is necessarily creative. It is the opposite of destruction. Human beings are delicate. Keeping the Commandments is the minimum Law. Jesus said to the rich young man, to enter Heaven one must keep the Commandments. But He went on to say, "If you want to be perfect, go and sell all that you have, give the money to the poor, and come and follow me." Jesus is love, so we too must love. Indeed, the Final Judgement, Matthew 25, records that love is helping our neighbour in his or her needs. "When I was hungry, you gave me to eat. When I was thirsty, you gave to drink. "etc. It is about helping our neighbour. Whom is our neighbour? Our worst enemies. Recall the good Samaritan helping his enemy. It cost him, but he did it for the sake of humanity. If we have no love, then society breaks down to "every man for himself." Jesus taught, that it should be, "we are all in it together." If we are not all in it together, we are animals. If we are animals, humanity no longer exists. God declared Himself, as "I AM". I exist in other words. Love of neighbour is the only prescription for humanity. Thus, the Humanities matter.

There is a balance between licence (freedom) and duty (rules to live by). Ancient rules given to Man by god, came from Moses' visit to Mt Sinia around 1200 B.C.E. God gave him the Decalogue-better known as the Ten Commandments. The first three Commandments deal with Man's duty to God; the last 7 deal Man's duty to Neighbour and Self (Figure 1)

I repeat the 10 Commandments here for those unfamiliar with them Book of Exodus 20:

- I am the Lord, they God; Thou shalt have no false gods before me

- Do not take the Lord Thy God's Name in Vain

- Keep Holy the Sabbath

- Honour They Father and Mother

- Thou Shalt not kill

- Thou shalt not commit adultery
- Thou shalt not steal

- Do not bear false witness against their neighbour

- Thou shalt not covet they neighbours Wife

- Thou shalt not covet they neighbours goods.

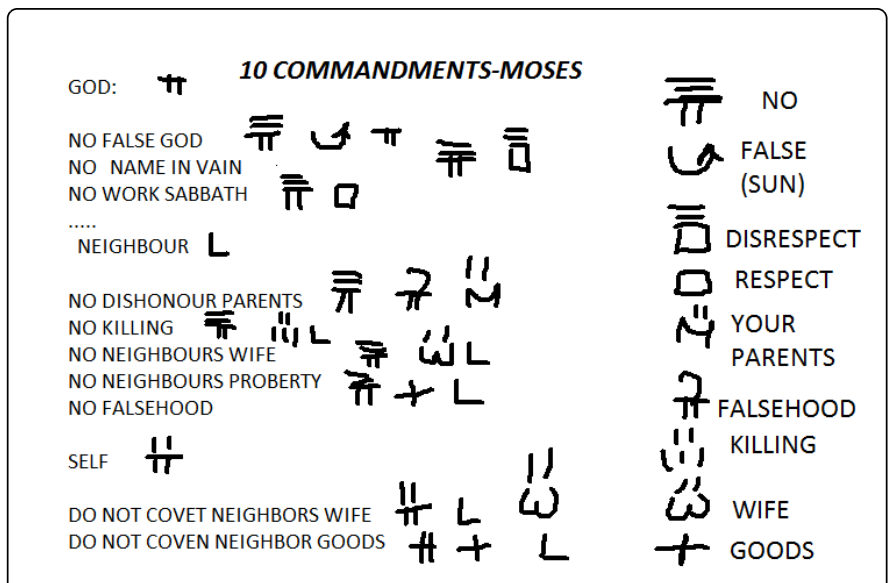

Figure 1: Minoan tablet, The Hebrew Civilization, P T E Cusack.

These then are the ten rules (not suggestions) God gave man to live by. It is the foundation of Society entrusted to the Hebrews in their 40 years of wandering in the Sinai Desert though Moses before they established a society in Israel [1].

An English professor of mine explained the balance between freedom, licence and responsibility toward God, self and neighbour. "You can swing your fists as long as you like until you reach the end of my nose." He said. First, why must man have a duty to God anyway? Because, the first Commandment puts all other laws in place. If we don't put God first in our lives, then the other 9 commandments don't matter as much. They are of vital importance to form a society as we shall see. The second and third commandments must do with how we honour God: by respecting His Name and His Holy day. We tithe a day to God and respect his holy Name to show that we are not god and $\mathrm{He}$ is; we should respect him for that reason alone.

The next 7 Commandments deal with duty to self and Neighbour. Honouring Father and mother means looking after them when they are old and need our help. The next 3 prohibit killing, lying, and stealing. Coveting is what tears the human mind apart. Its core is envy. 
Page 2 of 2

Jesus said, If the eye in you is diseased, the whole body will be diseased." He is peaking of the "green eye of envy". Why are these ancient rules necessary?

To form a Society, we need to be able to trust on another. A Society is cooperation between the members of that society. If you can't trust your neighbour, you can't cooperate with him or her. If you can't cooperate, societal rules continue to break down and its becomes a race to the bottom of chaos. Without Laws to live by, chaos ensues and humanity becomes animalistic- survival of the fittest at all cost- or the law of the "concrete jungle" in popular parlance.

The Human Society requires cooperation to accomplish great feats such as putting Man on the Moon. This required enormous cooperation. On the other hand, putting lethal power into the hands of those who are in a race to the bottom, results are a catastrophic war (viz., Armageddon). On a smaller scale, lack of following the rules results in crime and hatred, and a distrust of everyone, and thus no cooperation. We live, then in an unsafe, primitive, animalistic environment. Civilized people don't want to live like that. Some brutes do.

So, we see, that obeying the God given Commandments were necessary for the Western Civilization to advance as far as it did. It was the death of these rules that lead to the downfall of the most advanced civilization ever created by Man.
If the West is to re-establish itself predominance and continue to achieve amazing feats, the Decalogue must be at it foundation. Since the Women are the first teachers of the children, and they reject the Church en-mass because of a false Feminism, ("If you won't take my son, you can't have my daughter"), then the West is in dire straits indeed. How will the West recover its prominence without the Decalogue without is foundation? Of course, the sinful, mostly homosexual priests did their fair share to finally to destroy the Church too.

\section{Conclusion}

Thus, we have no society or Sociology if we have no trust in our fellow citizens. If the West doesn't recover the Ten Commandments, all may be lost and humanity will be in for another long Dark Age at best, if we don't annihilate ourselves first (which is more likely).

\section{References}

1. The Christian Community Bible, Caretian Publications, St Pauls. 1999. Phillipines. 